\title{
Analysis of Thoracic Trauma Patients who were Treated in the Thoracic Surgery Clinic
}

\author{
- Cenk Balta, Mustafa Kuzucuoğlu
}

Department of Thoracic Surgery, Balıkesir University, Balıkesir, Turkey

Submitted: 08.11.2019 Accepted: 13.03.2020

Correspondence: Cenk Balta Balıkesir Üniversitesi, Göğüs Cerrahisi Anabilim Dalı, Balıkesir, Turkey

E-mail: drcenkbalta@gmail.com

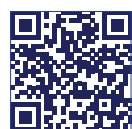

Keywords: Blunt injury; chest trauma; penetrating injury; thoracotomy.

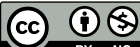

This work is licensed under a Creative Commons Attribution-NonCommercial 4.0 International License.

\section{ABSTRACT}

Objective: We aimed to evaluate the etiology, traumatic pathology and treatment of thoracic trauma patients who were treated in thoracic surgery clinic.

Methods: Patients with thoracic trauma admitted to the thoracic surgery clinic between September 2017 and September 2019 were evaluated retrospectively in terms of age, gender, types of trauma, thoracic and extrathoracic injuries, treatments and hospitalization time.

Results: The mean age of 119 patients ( 92 males and 27 females) was 43.65 years. Eighteen (15.I\%) patients were presented with penetrating trauma and 101 (84.9\%) patients with blunt thoracic trauma. The most common pathologies in blunt traumas were rib fracture and contusion and in penetrating traumas were pneumothorax and hemothorax. Medical treatment was usually sufficient for patients with blunt thoracic trauma. The most common surgical method in penetrating injuries were tube thoracostomy.

Conclusion: Thoracic traumas must be treated quickly and effectively due to their high mortality rates.

\section{INTRODUCTION}

Trauma-related deaths are the most common cause of deaths in the first 4 decades worldwide. It ranks $3^{\text {rd }}$ in death causes of all ages, after cancer and cardiovascular diseases. ${ }^{[I]}$ Thoracic trauma is the most common cause of death after cranial trauma in trauma-related deaths. ${ }^{[2]}$ Thoracic traumas include a wide spectrum from rib fractures to major vascular injuries.

Thoracic traumas are examined in two groups as blunt and sharp. Blunt traumas constitute $90 \%$ of all thoracic traumas. Although penetrating traumas are observed less frequently, mortality rate is higher. While $25 \%$ of thoracic traumas are in the form of isolated trauma, $75 \%$ occur in the form of multiple trauma together with other system traumas. Mortality rate increases in the presence of additional pathologies. ${ }^{[3]}$

Mortality rates may decrease with simple interventions as a result of rapid diagnosis of pathophysiological changes in thoracic traumas. Major surgical intervention is approximately $10 \%$ in blunt traumas and $15-30 \%$ in penetrating traumas. ${ }^{[4]}$

In our study, in the light of current literature, we aimed to evaluate patients who were admitted to the emergency department or thoracic surgery outpatient clinic and hospitalized in the thoracic surgery clinic.

\section{MATERIALS AND METHODS}

Patients with thoracic trauma who were admitted to the thoracic surgery clinic and inpatients admitted to the thoracic surgery clinic between September 2017 and September 2019 were included in our study. The patients were retrospectively analyzed from the patient files in terms of age, gender, type of trauma, thoracic and extrathoracic injuries, treatments applied, and length of hospital stay.

The data obtained were evaluated statistically. Statistical Package for Social Sciences (SPSS) version 22 program was used for statistical analysis. Descriptive statistics of the data were made. Mean ( \pm standard error) values of numerical continuous data suitable for normal distribution were presented. Chi-Square test and Fischer exact test were used for the analysis of the relationship between the groups. In all statistical analyzes, $\mathrm{P}$ values below 0.05 were considered significant.

\section{RESULTS}

The mean age of I 19 patients (92 male and 27 female) was $43.65 \pm 1.71$ who included in our study. 18 (15.1\%) of the patients applied due to penetrating and I0I (84.9\%) due to blunt thoracic trauma. While the patients presenting with 
penetrating trauma were in the form of firearm injuries or stab wounds, the patients admitted due to blunt trauma were injuries caused by traffic accidents, assaults and falls. While traffic accidents $(n=60,50.4 \%)$ and falling from height $(n=31,26 \%)$ were the most common blunt trauma, in penetrating traumas the rate of stab wounds $(n=16)$ was higher than the rate of gunshot wounds $(n=2)$ (Fig. I).

When the patients were evaluated in terms of traumatic pathologies, pneumothorax and hemothorax were statistically significantly more common in penetrating thoracic traumas, while pulmonary contusion and rib fracture were more common in blunt thoracic traumas compared to penetrating traumas. While pneumothorax occurred in $45,5 \%$, and hemothorax occurred in $33.7 \%$ after blunt trauma, rib fracture and pulmonary contusion rates were determined as equal (69.3\%). After penetrating thoracic traumas, pneumothorax was observed with a rate of $94.4 \%$, hemothorax in $88.9 \%$ and pulmonary contusion with a rate of $16.7 \%$, whereas rib fracture was not observed (Table I).

When the patients with blunt trauma and penetrating trauma were evaluated in terms of traumas associated with thoracic trauma, no statistically significant difference was found $(p=0.07)$. Diaphragmatic injury accompanying thoracic trauma was detected in I patient with penetrating trauma. While accompanying traumatic pathology was found in 26 patients with blunt thoracic trauma, the most common accompanying pathology was skeletal system pathologies seen in 16 patients.

While follow-up and medical treatment was sufficient in $88.1 \%$ of the patients with blunt thoracic trauma, $55.6 \%$ of the patients with penetrating thoracic trauma required surgical procedure. Statistically, it was found that patients

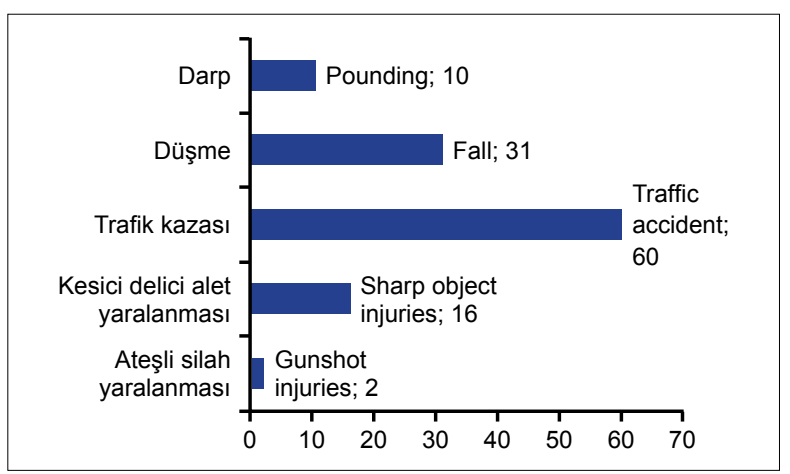

Figure 1. Distribution of trauma patients. with penetrating trauma required more surgical procedures $(p<0.001)$. While tube thoracostomy was performed to 18 of the trauma patients, 2 patients underwent primary repair due to diaphragm rupture, I patient underwent parenchymal repair due to massive air leakage, and I patient underwent explorative thoracotomy due to hemorrhage of more than $1500 \mathrm{cc}$ following tube thoracostomy.

\section{DISCUSSION}

$1 / 3$ of the patients who are admitted to the emergency department and hospitalized due to trauma are patients with thoracic trauma. ${ }^{[1]}$ Yalçınkaya et al. ${ }^{[5]}$ found this rate as $29.7 \%$, while Battistella et al. ${ }^{[6]}$ stated it as $1 / 3$.

Blunt thoracic traumas occur more frequently than penetrating traumas. Blunt thoracic traumas are held responsible for more than 150.000 deaths every year in Europe and the USA. ${ }^{[7]}$ Çakan et al. ${ }^{[8]}$ determined $72 \%$ of the traumas as blunt and $28 \%$ as penetrating traumas in their study. In our study, $15.1 \%$ of the cases were penetrating and $84.9 \%$ were blunt. In our study, the most common trauma etiology was traffic accidents with a rate of $50.4 \%$. Studies show a difference in traffic accident rates and the most common etiologies..$^{[9-11]}$ While Kulshrestha et al. ${ }^{[9]}$ found rib fracture as the most common traumatic pathology in patients with blunt thoracic trauma with $48.7 \%$ in their study, the most common pathologies in our study were rib fracture and lung contusion with a rate of $69.3 \%$. This rate is $32.1 \%$ in the study of Demirhan et al. ${ }^{[10]}$ and around $57 \%$ in the study of Yetim et al. ${ }^{[1]}$ These different rates should be evaluated according to the sociocultural changes in the centers where the studies were conducted.

Although penetrating traumas are observed less frequently, they have a more fatal course, especially the majority of injuries that cause major cardiovascular injury result in mortality at the scene. Tube thoracostomy is sufficient in 90-95\% of penetrating thoracic traumas that do not cause cardiovascular injury. ${ }^{[12]}$ Since patients with penetrating thoracic trauma included in our study were hospitalized and treated, no mortality was observed in our study.

Although thoracic traumas generally cause serious problems, less than $50 \%$ of them require surgical intervention. [13] After the tube thoracostomy to be applied, there is no need for advanced surgical intervention in $95 \%$ of the cases. ${ }^{[9]}$ While tube thoracostomy was performed in 18 (I5.I\%) of the cases in our study, 4 (3.3\%) patients re-

Table I. Trauma type and relationship between traumatic pathologies

\begin{tabular}{lcccc}
\hline & Total & Blunt trauma (n) (\%) & Penetrating trauma (n) (\%) & p \\
\hline Pneumothorax & 63 & $46(45.5 \%)$ & $17(94.4 \%)$ & $<0.001$ \\
Hemothorax & 50 & $34(33.7 \%)$ & $16(88.9 \%)$ & $<0.001$ \\
Ric fracture & 70 & $70(69.3 \%)$ & $0(0 \%)$ & $<0.001$ \\
Pulmonary contusion & 73 & $70(69.3 \%)$ & $3(16.7 \%)$ & $<0.001$ \\
Sternal fracture & 5 & $5(5 \%)$ & $0(0 \%)$ & 1 \\
\hline
\end{tabular}


quired thoracoscopy or thoracotomy. Thoracotomy rates were $2.6 \%$ in the study of Kulshrestha et al., ${ }^{[9]}$ while it was $6 \%$ in the study of Demirhan et al. ${ }^{[10]}$ With the introduction of videothoracoscopic surgery in trauma patients, thoracotomy rates have decreased even more. We also preferred the videothoracoscopic approach in 4 patients whose hemodynamic findings were stable, and we performed videothoracoscopic diaphragm repair in 3 patients and videothoracoscopic parenchymal repair in I patient.

Thoracic trauma usually occurs together with other system traumas, and isolated thoracic trauma is rarely detected. In $26(21.8 \%)$ of our cases, additional traumatic pathology was found and the most common traumatic pathology was extremity fractures with $13.4 \%$. In the study of Demirhan et al., ${ }^{[10]}$ this rate was found to be $35 \%$ and it was stated that mortality and hospital stay increased in patients with multiple trauma compared to isolated thoracic trauma.

In conclusion, rapid and effective treatment of thoracic traumas with high mortality rates is very important in reducing mortality rates. Surgically, tube thoracostomy requires videothoracoscopic approaches and thoracotomy by providing adequate treatment in most of the patients. It should be kept in mind that other system traumas may accompany thoracic traumas and detailed systemic evaluation should be performed in trauma patients.

Ethics Committee Approval

Balıkesir University Local Ethics Comittee Decision No: 2019/142, Date: 09.10.2019.

Informed Consent

Retrospective study.

Peer-review

Internally peer-reviewed.

Authorship Contributions

Concept: C.B., M.K.; Design: C.B., M.K.; Supervision: C.B.; Fundings: C.B., M.K.; Materials: C.B., M.K.; Data: C.B., M.K.; Analysis: C.B., M.K.; Literature Search: C.B.; Writing: C.B.; Critical Revision: M.K.
Conflict of Interest

None declared.

\section{REFERENCES}

1. Julian G, Lynn C. Huffman, et al. Blunt and penetrating injuries of the chest wall, pleura, and lungs. In: Shields TW, Locicero J 3rd, Reed CE, Feins RH, editors. General Thoracic Surgery. 7th ed. Lippincott Williams \& Wilkins, 2009. p. 891-902.

2. Ludwig C, Koryllos A. Management of chest trauma. J Thorac Dis 2017;9:S172-S177. [CrossRef]

3. Balta C. Management of Thoracic Traumas: Analysis of 28 Patients. International Annals of Medicine 2018;2. [CrossRef]

4. Kaiser LR. Thoracic trauma. In: Kaiser LR, Singhal S, editors. Essentials of thoracic surgery. Elsevier 2004. p. 99-124.

5. Yalçinkaya I, Sayir F, Kurnaz M, Cobanoğlu U. Chest trauma: analysis of 126 cases. Ulus Travma Acil Cerrahi Derg 2000;6:288-91.

6. Battistella FD, Benfield JR. Blunt and penetrating injuries of the chest wall, pleura and lungs. In: Shields TW, LoCicero J 3rd, Ponn RB, editors. General thoracic surgery. 5th ed. Philadelphia: Lippincott Williams \& Wilkins; 2000. p. 815-31.

7. Bertoglio P, Guerrera F, Viti A, Terzi AC, Ruffini E, Lyberis P, Filosso PL. Chest drain and thoracotomy for chest trauma. J Thorac Dis 2019;11(Suppl 2):S186-S191. [CrossRef]

8. Cakan A, Yuncu G, Olgaç G, Alar T, Sevinç S, Ors Kaya S, et al. Thoracic trauma: analysis of 987 cases. Ulus Travma Acil Cerrahi Derg 2001;7:236-41.

9. Kulshrestha P, Munshi I, Wait R. Profile of chest trauma in a level I trauma center. J Trauma 2004;57:576-81. [CrossRef]

10. Demirhan R, Onan B, Oz K, Halezeroglu S. Comprehensive analysis of 4205 patients with chest trauma: a 10-year experience. Interact Cardiovasc Thorac Surg 2009;9:450-3. [CrossRef]

11. Yetim TD, Yetim İ, Duru M, Bayaroğulları H. Thoracic Trauma: 156 Patient Assessment. JAEM 2011;1:110-3. [CrossRef]

12. Molnar TF. Thoracic Trauma: Which Chest Tube When and Where? Thorac Surg Clin 2017;27:13-23. [CrossRef]

13. Simon B, Ebert J, Bokhari F, Capella J, Emhoff T, Hayward T 3rd, et al; Eastern Association for the Surgery of Trauma. Management of pulmonary contusion and flail chest: an Eastern Association for the Surgery of Trauma practice management guideline. J Trauma Acute Care Surg 2012;73(5 Suppl 4):S351-61. [CrossRef]

\section{Göğüs Cerrahisi Kliniğinde Yatarak Tedavi Edilen Toraks Travmalı Hastaların Analizi}

Amaç: Göğüs cerrahisi kliniğinde yatırılarak tedavi edilen toraks travma hastalarııın etyoloji, travmatik patoloji ve tedavi açısından değerlendirmeyi amaçladık.

Gereç ve Yöntem: Eylül 2017-Eylül 2019 tarihleri arasında travma nedeniyle başvuran ve göğüs cerrahisi kliniğine yatırılarak tedavi edilen toraks travmalı hastalar yaş, cinsiyet, travma şekli, torasik ve ekstratorasik yaralanmaları, uygulanan tedaviler, hastanede yatış süreleri açısından retrospektif olarak incelendi. Elde edilen verilerek istatistiksel olarak değerlendirildi.

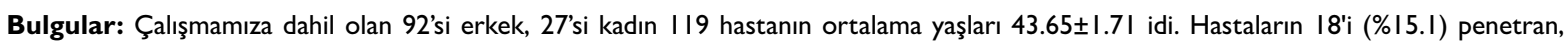
I0I'i (\%84.9) ise künt toraks travması nedeniyle başvurmuştu. Künt travmalarda en sık rastalanan patolojiler kot fraktürü ve kontüzyonken, penetran travmalarda en sık rastlanan patolojiler pnömotoraks ve hemotorakstı. Künt toraks travmalı hastalara medikal tedavi çoğunlukla yeterli olurken, penetran yaralanmalarda en sık kullanılan cerrahi yöntem tüp torakostomiydi.

Sonuç: Toraks travmaları yüksek mortalite oranları nedeniyle hızlı ve etkin tedavi edimesi gereken patolojilerdir.

Anahtar Sözcükler: Künt yaralanma; penetran yaralanma; toraks travmasl; torakotomi. 